\title{
KEBEBASAN PERS DALAM PERSPEKTIF PERADILAN PIDANA
}

\author{
Vivi Ariyanti"
}

"Penulis adalah dosen Junusan Syariah (Hukum Islam) STAIN Purwokerto.

Abstract: Freedom of the press in the perspective of the criminal justice is the use of the provisions of the Criminal Code; it is not limitation or restraint on freedom of the press, because the provision was only a tool that is used for the testing of limitotive conduct a press working process. Testing can be done by using specific parameters as stipulated in the convention on the freedom of information, such as the press can not be prosecuted in criminal low except when to do positive things like contempt, sedifion, blasphemy, pomography, a lie news, disturb national security and public order and statements that impede the fail administration of justice. Therefore, in press freedom, presenting news must be based on features news joumalist code of ethics that exist. Keywords: freedom, press, perspective, justice, criminal.

\section{A. PENDAHULUAN}

Setelah lebih dari 32 tahun mengalami berbagai pengekangan, pers Indonesia saat ini mengalami kebebasan baru. Kebebasan itu kemudian memperlihatkkkan kebijakan pemberitaan yang agresif dan kritis, terutama yang berkaitan dengan hak-hak asasi manusia. Meskipun pers Indonesia saat ini mengalami tarik-menarik kepentingan antara nasionalisme dan universalisme, idealisme, dan industri pers, namun kebebasan pers yang terbuka sebagai hasil proses reformasi, mutlak dijaga. Hal ini dikarenakan salah satu prasyarat demokrasi adalah pers yang bebas. ${ }^{1}$

Kebebasan pers merupakan satu unsur penting dalam pembentukan sistem bernegara yang demokratis, terbuka dan transparan. Pers sebagai media informasi merupakan pilar keempat demokrasi yang berjalan seiring dengan penegakan hukum untuk terciptanya keseimbangan dalam suatu negara. Oleh karena itu, sudah seharusnya pers sebagai media informasi menjadi media koreksi dijaminnya kebebasannya dalam menjalankan profesi kewartawanannya. Hal ini penting untuk menjaga objektifitas dan transparansi dalam dunia pers sehingga pemberitaan dapat dituangkan secara sebenar-benarnya tanpa ada rasa takut atau di bawah ancaman sebagaiman masa Orde Baru berkuasa (self-censorship). ${ }^{2}$

Walaupun pers begitu penting dalam penegakan demokrasi, tetapi harus diakui bahwa pers di Indonesia belum seluruhnya menerapkan kualitas pers yang profesional dan bertanggung jawab dalam membuat pemberitaan. Hal ini patut diwaspadai mengingat belum seluruh rakyat Indonesia memiliki pendidikan dan tingkat intelegensia yang memadai. Jika pers dibiarkan berjalan tanpa kontrol dan tanggung jawab, maka dapat berpotensi menjadi media agitasi, yang dapat memengaruhi psikologis masyarakat yang belum terdidik. Oleh karena itu, kebebasan pers perlu diberikan pembatasanpembatasan, paling tidak melalui rambu hukum sehingga pemberitaan yang dilakukan oleh pers dapat menjadi pemberitaan pers yang bertanggungjawab.

Dengan adanya era reformasi, terjadi perubahan konsep mengenai freedom of the press. Di satu sisi, ia termotivasi teori libertarian, namun di sisi lain terus dibayangi teori otoritarian. Hal itu merefleksikan kondisi masyarakat dan kehidupan politik yang sedang berubah amat cepat. Namun demikian, saat muncul pengertian pers merupakan the fourth estate atau pilar keempat demokrasi di Indonesia dan terutama setelah merebak istilah pers "kebablasan" (abuse of freedom), maka dapat diketahui bahwa pers bisa mengubah masyarakat dan kehidupan politik. ${ }^{3}$

Banyak kasus yang melibatkan pers seperti kasus harian Rakyat Merdeka, majalah Trust dan Tempo, dan kasus PT Toba Pulp Lestari Tbk (TPL) yang kecewa dengan pemberitaan majalah mingguan Tempo edisi 5-11 Juli 2004 yang lalu. ${ }^{4}$ Pemberitaan-pemberitaan tersebut bersifat sepihak dan membuat kesan pers mulai kebablasan atau terlalu bebas sehingga 
merugikan pihak-pihak yang diberitakan. Ketika pihak-pihak yang dirugikan tersebut hendak mengajukan permasalahannya ke meja hijau, mereka merasa tidak memiliki payung hukum secara pidana yang kuat karena terbentur dengan alasan kebebasan pers. Oleh karena itu, tulisan singkat ini berusaha untuk mengkaji tentang kebebasan pers dalam perspektif peradilan pidana.

\section{LANDASAN DAN PERANAN PERS}

Kebebasan mengemukakan pendapat (freedom of expression) merupakan refleksi praktis dari kebebasan berpikir (freedom of thought) yang bersifat individual dan merupakan salah satu bentuk Hak Asasi Manusia (HAM) yang sangat fundamental. Hal ini diatur secara universal oleh konstitusi negara-negara di dunia, sesuai dengan sistem politik yang dianutnya. (when studying laws geverning public information, is by definition imposible to ignore the political factors which, in effect, shape them). 5

Di Indonesia, nilai-nilai kebebasan pers telah diakomodir di dalam UUD 1945 yang telah diamandemen, yaitu diatur dalam Pasal 28 E Ayat (2) dan (3) serta Pasal 28 F. Fakta di tengah masyarakat dapat dibedakan antara informasi melalui pers dan Trial by the Press, mengeluarkan pikiran dengan lisan dan tulisan. Implementasi dari Pasal 28 Undang-undang Dasar 1945 adalah dengan keluarnya Undang-undang Nomor 40 Tahun 1999 tentang Pers. Pers yang meliputi media cetak, media elektronik dan media lainnya merupakan sarana untuk mengeluarkan pikiran dengan lisan dan tulisan tersebut. Hal ini menunjukkan bahwa negara telah mengakui kebebasan mengemukakan pendapat dan kebebasan berpikir adalah bagian dari perwujudan negara yang demokratis dan berdasarkan atas hukum.

Pers yang memiliki kemerdekaan untuk mencari dan menyampaikan informasi juga sangat penting untuk mewujudkan Hak Asasi Manusia yang dijamin dengan Ketetapan Majelis Permusyawaratan Rakyat Republik Indonesia Nomor: XVII/MPR/1998 tentang Hak Asasi Manusia. Hal itu antara lain menyatakan bahwa setiap orang berhak berkomunikasi dan memperoleh informasi sejalan dengan Piagam Perserikatan Bangsa-bangsa tentang Hak Asasi Manusia Pasal 19 yang berbunyi: "Setiap orang berhak atas kebebasan mempunyai dan mengeluarkan pendapat. Dalam hal ini termasuk kebebasan memiliki pendapat tanpa gangguan, dan untuk mencari, menerima, dan menyampaikan informasi dan pikiran melahi media apa saja dan dengan tidakmemandang batas-batas wilayah".

Dalam pemeriksaan persidangan pengadilan, tidak dapat dilepaskan dari fungsi pers untuk mengadakan pemberitaan, dan reportase tentang jalannya peradilan. Hal ini berkaitan dengan asas hukum persidangan terbuka untuk umum, kecuali untuk perkara yang berkaitan dengan kesusilaan atau terdakwanya anak-anak. ${ }^{6}$

Menurut Prof. Oemar Seno Adji, fungsi dari pada pers adalah sebagai; 1) Kritik, 2) Barometer, 3) Petunjuk, 4) Pengontrol.7 Sementara itu, berhasil atau tidaknya pers melaksanakan fungsinya tergantung dari beberapa faktor: Pertama, faktor manusia sebagai pemilik dan penyelenggara pers. Kedua, sikap penguasa terhadap pers. Ketiga, taraf kemajuan masyarakat. Keempat, keadaan alat-alat teknikyang tersedia. ${ }^{8}$

Kebebasan pers sekarang ini terjadi karena jatuhnya Soeharto, Mei 1998, yang segera memberi ruang terbuka bagi sesak nafas yang diderita Pers Indonesia selama tiga dasawarsa.

\section{PERKEMBANGAN PERS DI INDONESIA}

Soeharto dan Departemen Penerangan adalah lembaga kontrol yang dua dasawarsa lebih menjadi hantu pencabut nyawa bagi pers. Hal itu dibredel oleh Presiden Abdurrahman Wahid pada Oktober 1999. ${ }^{9}$ Presiden Abdurrahman Wahid yang baru terpilih itu menegaskan, informasi adalah urusan masyarakat, bukan lagi menjadi urusan pemerintah. Pembubaran Departemen Penerangan menandai hilangnya kontrol negara. Selanjutnya siapa mengontrol pers? Itu sebabnya dua tahun terakhir ini (kelompok tertentu) masyarakat aktif mengontrol pers, dengan menduduki kantor redaksi, mengintimidasi wartawan, dan memaksakan agar versi mereka dimuat di pers. Babak baru perkembangan pers Indonesia sedang berlangsung. 
Periode kebebasan pers pernah dinikmati di Indonesia pada tahun 1945-1949, ketika merdeka dari penguasa kolonial Belanda dan Jepang, kemudian tahun 1966-1972, setelah tumbangnya Soekarno, dan pasca tumbangnya Soeharto. Jatuhnya Soeharto ternyata tidak dengan sendirinya mengakhiri berbagai persoalan. Periode transisi, di era Presiden Habibie berlanjut ke Presiden Abdurahman Wahid, suasana keterbukaan justru memunculkan berbagai persoalan baru yang lebih kompleks, tidak sekadar hitam-putih.

Rezim Habibie tidak punya pilihan lain, selain harus melakukan liberalisasi dan itu pun bukan tanpa ancaman. Era Abdurrahman Wahid memperlihatkan kesungguhan untuk mengadopsi kebebasan pers. Dalam era SBY-Boediono, masalah penegakan kebebasan pers masih harus ditunggu. Ancaman terhadap kebebasan pers semula datang dari pemerintah melalui berbagai aturan represif beralih wujud melalui tekanan massa serta ancaman internal, yakni tumbuhnya penerbitan pers yang sensasional dan tidak mengindahkan etika.

Peraturan pertama mengenai pers di zaman Hindia Belanda dituangkan pada 1856, dalam Reglement op de Drukweken in Nederlandsch Indie yang bersifat pengawasan preventif. Aturan ini pada 1906 diperbaiki menjadi bersifat represif, yang menuntut setiap penerbit mengirim karya cetak ke pemerintah sebelum dicetak. Dua puluh lima tahun kemudian, pada 1931, pemerintah kolonial melahirkan Persbreidel Ordonnantie. Aturan ini memberikan hak kepada Gubernur Jendral untuk melarang penerbitan yang dinilai bisa mengganggu ketertiban umum. ${ }^{10}$ Selain itu, pemerintah kolonial Belanda juga memiliki pasal-pasal terkenal, Haatzaai Artikelen, yang mengancam hukuman terhadap siapapun yang menyebarkan perasaan permusuhan, kebencian, atau penghinaan terhadap pemerintah Nederland atau Hindia Belanda berlaku sejak 1918.

Selanjutnya, pada zaman pendudukan Jepang, untuk wilayah Jawa dan Madura diterapkan Undang-undang No. 16 yang memberlakukan sistem lisensi dan sensor preventif. Setiap penerbitan cetak harus memiliki izin terbit serta melarang penerbitan yang dinilai memusuhi Jepang. Aturan itu masih diperkuat lagi dengan menempatkan shidooin (penasehat) dalam staf redaksi setiap surat kabar. Tugas penasehat adalah mengontrol dan menyensor, bahkan adakalanya menulis artikel-artikel dengan memakai nama para anggota redaksi."

Sejumlah aturan yang diterapkan pada era penjajahan itu ternyata tetap dipelihara oleh pemerintah Republik Indonesia setelah memproklamasikan kemerdekaan. Misalnya, ketentuan yang tertuang dalam Persberidel Ordonnantie ${ }^{2}$ terus dipakai dan secara formal baru diganti pada 1954. Mengikuti perkembangan politik, pada 14 September 1956, Kepala Staf Angkatan Darat, selaku Penguasa Militer, mengeluarkan peraturan No. PKM/001/o/1956. Pasal 1 peraturan ini menegaskan larangan untuk mencetak, menerbitkan dan menyebarkan serta memiliki tulisan, gambar, klise atau lukisan yang memuat atau mengandung kecaman atau penghinaan terhadap presiden dan wakil presiden. Larangan itu juga berlaku bagi tulisan dan gambar yang dinilai mengandung pernyataan permusuhan, kebencian atau penghinaan. Ketentuan yang sangat mirip dengan Haatzaai Artikelen ini, kemudian dicabut setelah diprotes kalangan pers.

Mengikuti penerapan situasi darurat perang (SOB), Penguasa Militer Daerah Jakarta Raya mengeluarkan ketentuan ijin terbit pada 1 Oktober 1958. Pembredelan pers di era Soekarno banyak terjadi setelah pemberlakuan SOB, 14 Maret 1957, termasuk penahanan sejumlah wartawan. Aturan soal izin terbit bagi harian dan majalah kemudian dipertegas dengan Penpres No. 6/1963.

Aturan yang menindas pers itu terus dilestarikan pada era Soeharto. Represi sudah dijalankan bahkan sejak pada awal era Orde Baru; orde yang menjanjikan keterbukaan. Sejumlah koran menjadi korban, antara lain majalah SENDI terjerat delik pers pada 1972 karena memuat tulisan yang dianggap menghina Kepala Negara dan keluarga. Surat Izin Terbit (SIT) Sendi dicabut, pemimpin redaksinya dituntut di pengadilan. Setahun kemudian, 1973, Sinar Harapan dilarang terbit seminggu karena dianggap membocorkan rahasia negara akibat menyiarkan Rencana Anggaran Belanja yang belum dibicarakan di parlemen. ${ }^{3}$

Pada 1974, setelah meledaknya Peristiwa Malari, sebanyak 12 penerbitan pers dibredel melalui pencabutan Surat Izin Terbit (SIT). ${ }^{4}$ Pers dituduh telah menjurus ke arah usaha-usaha melemahkan sendi-sendi kehidupan nasional, dengan mengobarkan isu-isu seperti modal asing, korupsi, dwi fungsi, kebobrokan aparat pemerintah, pertarungan tingkat tinggi, merusak kepercayaan masyarakat pada kepemimpinan nasional, menghasut rakyat untuk bergerak mengganggu ketertiban dan 
keamanan negara, dan menciptakan peluang untuk mematangkan situasi yang menjurus pada perbuatan makar. Pencabutan SIT ini dipertegas dengan pencabutan Surat Ijin Cetak (SIC) yang dikeluarkan oleh Laksus Kopkamtib Jaya.

Pemberangusan terhadap pers kembali terjadi pada 1978 berkaitan dengan maraknya aksi mahasiswa menentang pencalonan Soeharto sebagai presiden. Sebanyak tujuh surat kabar di Jakarta (Kompas, Sinar Harapan, Merdeka, Pelita, The Indonesian Times, Sinar Pagi dan Pos Sore) dibekukan penerbitannya untuk sementara waktu hanya melalui telepon dan diizinkan terbit kembali setelah masing-masing pemilik koran tersebut meminta maaf kepada pemimpin nasional (Soeharto). ${ }^{15}$

Kisah pembredelan di era Soeharto terus berlanjut. Era 1980-an meminta korban, antara lain; pada 1982 majalah Tempo ditutup untuk sementara waktu, ketika menulis peristiwa kerusuhan kampanye pemilu di Lapangan Banteng. Koran Jurnal Ekuin dilarang terbit pada Maret 1983 oleh Kopkamtib akibat menyiarkan berita penurunan patokan harga ekspor minyak Indonesia yang merupakan informasi off the record. Korban berikutnya adalah majalah Expo (Januari 1984) setelah memuat serial tulisan mengenai "Seratus Milyader Indonesia". Tulisan tersebut dinilai telah melakukan penyimpangan terhadap ketentuan perundangan yang mengatur manajemen penerbitan pers.

Dua bulan kemudian, giliran majalah Topik akibat menulis editorial "Mencari Golongan Miskin" (Topik, 14 Februari 1984) dan menurunkan wawancara imajiner dengan Presiden Soeharto berjudul "Eben menemui Pak Harto". Tulisan pertama dinilai beraliran ekstrim kiri dan ingin mengobarkan pertentangan antarkelas, sedangkan tulisan kedua dianggap bernada sinis, insinuatif dan tidak mencerminkan pers bebas dan bertanggung jawab.

Bulan Mei 1984, majalah Fokus dilarang terbit dan dicabut SIT-nya setelah menurunkan tulisan yang dianggap dapat mempertajam prasangka sosial. Berikutnya, pada 9 Oktober 1986, Sinar Harapan dilarang terbit. ${ }^{16}$

Deretan pembredelan itu terus berlanjut dengan korban koran Prioritas, tabloid Monitor, majalah Senang hingga pada 21 Juni 1994 ketika pemerintah membunuh Tempo, Editor dan Detik.

Pada era Orde Baru, pemerintahan Soeharto secara cerdik berhasil merumuskan sistem pers baru yang orisinil, yakni pers Pancasila. Hal ini merupakan satu labelisasi gaya Indonesia dari konsep development joernalism (atau dalam kategori Sieber, Peterson, dan Schramm termasuk dalam jenis social responsibility pers).

Konsep Pers Pembangunan atau Pers Pancasila (sering didefinisikan sebagai bukan pers liberal juga bukan pers komunis) secara resmi dirumuskan pertama kali dalam Sidang Pleno Dewan Pers ke-25 di Solo pada pertengahan 1980-an. Rumusan tersebut berbunyi: Pers Pembangunan adalah Pers Pancasila, dalam arti pers yang orientasi sikap dan tingkah lakumya berdasar nilai-nilai Pancasila dan UUD 45. Pers Pembangunan adalah Pers Pancasila, dalam arti mengamalkan Pancasila dan UUD 45 dalam pembangunan berbagai aspek kehidupan bermasyarakat, berbangsa, bernegara, termasuk pembangunan pers itu sendiri. Hakekat Pers Pancasila adalah pers yang sehat, yakni pers yang bebas dan bertanggung jawab dalam menjalankan fungsinya sebagai penyebar informasi yang benar dan objektif, penyaluran aspirasi rakyat dan kontrol sosial yang konstruktif. Melahi hakekat dan fungsi itu, Pers Pancasila mengembangkan suasana saling percaya memuju masyarakat terbuka yang demokrasi dan bertanggungjawab.

Pers Indonesia periode akhir 1970-an hingga 1998 semata-mata menjadi corong (mouthpiece) pemerintah, kehilangan independensi dan fungsi kontrolnya. Berbagai pembatasan yang dibuat rezim Soeharto membuat wartawan tidak bebas menulis. Pada era inilah muncul hal yang disebut secara sinis sebagai budaya telepon. Peringatan melalui telepon ini bisa dilakukan oleh siapa saja di kalangan aparat pemerintah untuk mencegah media menulis laporan tertentu yang tidak disukai pemerintah. Selain itu, pada pertengahan 1980-an juga mulai lazim kebiasaan pejabat militer dan pemerintah berkunjung ke kantor redaksi media cetak untuk memberikan informasi penting dan ketentuan tak tertulis yang boleh dan tidak boleh ditulis. Berbagai bentuk sensor ini mendorong pengelola media menggunakan gaya bahasa eufimistik untuk menghindarkan teguran dan pembredelan. Lebih jauh lagi, pers Indonesia semakin pintar untuk melakukan swasensor (self censorship). Akibatnya, sebagian besar media cetak saat itu bisa dikatakan menjadi corong pemerintah.

Pers dan wartawan yang tidak bebas, ikut mengajarkan rasa takut terhadap kebebasan pada masyarakat, atau mereka bersikap masa bodoh, sejauh keuntungan ekonomi masih diperoleh. Di era rezim Soeharto, sejak pertengahan 1980-an, pers 
Indonesia mulai mencicipi buah keuntungan era pers industri. Dalam pers industri, bisnis informasi ternyata menjanjikan keuntungan besar, dan tingkat kesejahteraan wartawan menjadi semakin baik. Namun, keuntungan finansial itu berbanding terbalik dengan kepedulian sosial yang makin menumpuk. Peningkatan oplah dan perolehan iklan menjadi tujuan. Akibatnya, yang menjadi prioritas pers Indonesia didukung pertumbuhan ekonomi yang tinggi adalah perolehan keuntungan, bukan

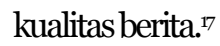

Pada era Soeharto, terdapat tiga faktor utama penghambat kebebasan pers dan arus informasi. Adanya sistem perizinan terhadap pers (SIUPP), adanya wadah tunggal organisasi pers. Faktor-faktor itulah yang telah berhasil menghambat arus informasi dan memandulkan potensi pers untuk lembaga kontrol.

\section{KEBEBASAN PERS DALAM PERSPEKTIF PERADILAN PIDANA}

Dr. Von Campe menyatakan bahwa sifat terbuka dari suatu proses pidana tidak begitu saja terletak pada dapatnya orang masuk dalam ruang persidangan, melainkan ia lebih terletak pada pemberitaan yang bebas oleh pers. ${ }^{18}$

Dalam persidangan yang terbuka di dalamnya terdapat 2 (dua) masalah dan ketentuan-ketentuan yuridis, yaitu hak seseorang untuk memperoleh pemeriksaan yang "fair" yang jujur dan tidak memihak (a fair trial). Di pihak lain, adanya suatu pers bebas yang dapat memberitakan jalannya peradilan (free perss). A fair trial dan free press harus seimbang. ${ }^{19}$

Pers mempunyai kewenangan untuk mengadakan komentar terhadap jalannya peradilan, tetapi pemberitaan itu harus dengan penuh tanggung jawab dan mengedepankan azas praduga tak bersalah sehingga pemberitaan itu tidak merupakan rintangan bagi jalannya peradilan yang fair dan objektif. Kebebasan dalam pemberitaan adalah kebebasan yang limitatif, yang dapat diwujudkan dalam ketentuan hukum, maupun yang merupakan suatu Zelf-oplegging, berupa moral/etika. Kebebasan ini tidak boleh mempengaruhi the fair administration of justice.

Dalam beberapa pemberitaan terhadap perbuatan pidana, seharusnya dibuktikan terlebih dahulu di pengadilan, namun sebelum masuk dalam persidangan, perlu dicatat besarnya liputan media massa. Mereka berlomba-lomba melakukan blocking coverage atau dalam khazanah pers di Indonesia dikenal dengan terminologi Blow Up. ${ }^{20}$ Blow up dalam liputan media massa terhadap suatu peristiwa besar karena ketokohan dan daya tarik peristiwa, adalah wajar saja. Dengan peliputan yang bersifat blow up, diharapkan fakta-fakta yang terungkap dan disampaikan kepada publik bersifat menyeluruh sehingga akurasinya lebih baik.

Persoalannya, liputan yang di-blow up dalam perkara tindak pidana tidak sepenuhnya berstandard pada dua realitas dalam porsi yang sama besar. Kesimbangan antara liputan bersandar pada realitas empiris dan realitas wacana. Realitas empiris adalah kumpulan atau penelusuran fakta-fakta melalui pelacakan di lapangan untuk memperoleh temuan informatif yang dilakukan pers. Misalnya, melalui pelacakan bukti-bukti di lapangan, penelusuran di instansi terkait, dan investigasi di sejumlah tempat yang diduga mengetahui suatu peristiwa. Adapun realitas wacana adalah pengumpulan fakta-fakta yang hanya besumber pada pernyataan, retorika dan wawancara dengan tokoh-tokoh yang dianggap terkait atau berkompeten mengenai peristiwaitu.

Pers besar dalam menyajikan pemberitaan berkaitan dengan terjadinya tindak pidana sangat timpang. Mereka masih berorientasi pada liputan yang bersumber pada realitas wacana. Kalaupun tidak berasal dari jaksa, mereka adalah orang-orang dekat atau penasehat hukum terdakwa yang berposisi membela, bahkan ada kecenderungan pemberitaan oleh pers lebih kepada mencari profit dari pada mencari kebenaran. Hal itu dapat dilihat dari menjamurnya media massa yang memberitakan tentang gosip-gosip selebritis, seperti perselingkuhan dan lain-lain.

Sampai sekarang, tidak ada jaminan bahwa realitas empiris lebih benar daripada realitas wacana. Belum tentu pengumpulan fakta-fakta yang bersandar pada realitas empiris lebih benar daripada pengumpulan fakta-fakta yang bersandar pada realitas wacana. Namun demikian, menurut konsepsi jurnalisme, liputan pers dan media massa berorientasi pada liputan di medan peristiwa. Fakta-fakta yang bisa ditunjukkan parameternya, bisa diukur dan diamati dan diasumsikan punya akurasi lebih tinggi. Liputan pers yang bersandar pada realitas empiris dianggap mendekati kebenaran faktual. 
Lagi pula, semakin besar liputan yang lebih banyak berorientasi pada realitas wacana. Pers dianggap meninggalkan fungsi mediasi yang harus mandiri dan independen. Selain itu, liputan yang lebih banyak berorientasi pada realitas wacana tanpa disadari akan membuka menyeret pers menjadi corong pihak-pihak yang berkepentingan terhadap peristiwa tertentu. Itu artinya pers membuka diri melakukan trial by the pers.

Karena itu, semakin besar blow up yang digunakan oleh pers dan media massa dengan orientasi realitas wacana (beritanya berasal dari wawancara dengan jaksa, LSM tanpa melakukan penelusuran bukti di lapangan dan pengumpulan fakta di lapangan dan mengkumpulkan fakta melalui investigasi) semakin besar juga terjadi trial by the pers. Sekurangkurangnya, dengan kecenderungan liputan seperti itu, pers turut menciptakan opini publik agar hakim hanya satu pilihan vonis, yaitu bersalah terhadap terdakwa.

Trial by the court tidak boleh menjadi trial by the perss karena pemberitaan yang cenderung memberikan opini terhadap bersalahnya seorang tersangka, di samping melanggar asas utama dari suatu negara hukum, yakni kebebasan kehakiman, juga merupakan pelanggaran hak asasi seseorang, yaitu mengurangi hak untuk membela diri secara yuridis. ${ }^{21}$ Adapun yang dimaksud membela secara yuridis adalah hak seseorang ketika diduga melakukan tindak pidana. Dia berhak untuk mendapat proses peradilan yang bebas, dan dia tidak bisa dikatakan bersalah sebelum ada putusan pengadilan yang mempunyai kekuatan hukum tetap. Hal ini dapat dilihat dalam pasal 24 UUD 1945 yang menyebutkan bahwa kekuasaan kehakiman dilakukan oleh Mahkamah Agung dan lain-lain badan kehakiman menurut Undang-undang, maka tidak ada pemberian kekuasaan di luar kehakiman dalam menghakimi seseorang. Dengan demikian, penghakiman oleh pers merupakan perbuatan yang melanggar konstitusi yaitu pasal 24 UUD 1945, dan hakim yang profesional tidak akan terpengaruh oleh tanggapan pers yang bebas.

Kemerdekaan pers merupakan sarana terpenuhinya hak azasi manusia untuk berkomunikasi dan memperoleh informasi. Dalam mewujudkan kemerdekaan pers, wartawan Indonesia menyadari adanya tanggung jawab sosial serta keberagaman masyarakat.

Guna menjamin tegaknya kebebasan pers serta terpenuhinya hak-hak masyarakat diperlukan suatu landasan/moral/etika profesi yang bisa menjadi pedoman operasional dalam menegakkan integritas dan profesionalitas wartawan. Atas dasar itu, wartawan Indonesia menetapkan kodeetik.

1. Wartawan Indonesia menghormati hak masyarakat untuk memperoleh informasi yang benar.

2. Wartawan Indonesia menempuh tata cara yang etis untuk memperoleh dan menyiarkan informasi serta memberikan identitas kepada sumber informasi.

3. Wartawan Indonesia menghormati asas praduga tak bersalah, tidak mencampurkan fakta dengan opini, berimbang, dan selalu meneliti kebenaran informasi serta tidak melakukan plagiat.

4. Wartawan Indonesia tidak menyiarkan informasi yang bersifat dusta, fitnah, sadis dan cabul, serta tidak menyebutkan identitas korban kejahatan susila.

5. Wartawan Indonesiatidak menerima suap, dan tidak menyalahgunakan profesi.

6. Wartawan Indonesia memiliki hak tolak, menghargai ketentuan embargo, informasi latar belakang dan off the record sesuai kesepakatan.

7. Wartawan Indonesia segera mencabut dan merelat kekeliruan dalam pemberitaan serta melayani hakjawab.

Pengawasan dan penetapan sanksi atas pelanggaran kode etik ini sepenuhnya diserahkan kepada jajaran pers dan dilaksanakan oleh organisasi yang dibentuk untukitu.

Setiap kebebasan pers, jurnalis selalu mendasarkan pada kode etik wartawan Indonesia. Akan tetapi, perlu dipahami bahwa Undang-undang pidana positif harus dipandang sebagai pembatasan yang sah terhadap kebebasan pers yang secara limitatif dan enumeratif dapat diterapkan bagi mereka yang menyalahgunakan kebebasan itu. Oleh karena itu, penggunaan ketentuan KUHP sama sekali bukan pemasangan atau pengekangan (ongebreided) terhadap kebebaan pers karena aneka ketentuan itu hanya sarana yang digunakan untuk secara limitatif melakukan pengujian terhadap proses bekerjanya pers. Pengujian itu dapat dilakukan dengan menggunakan parameter tertentu sebagaimana diatur dalam convention on the 
freedom of information. Misalnya, pers tidak dapat dituntut hukum pidana positif, kecuali bila melakukan hal-hal seperti penghinaan (fegamation), hasutan (incitement to violence and crime), blasphemy, pornograf, berita bohong, mengganggu national security dan public order dan pernyataan yang menghambat jalannya peradilan (impede the fair administration of justice).2

\section{PENUTUP}

Kebebasan pers dalam menyajikan berita merupakan salah satu unsur pilar negara demokrasi. Selain itu, pers juga memiliki kemerdekaan untuk mencari dan menyampaikan informasi penting untuk mewujudkan Hak Asasi Manusia. Akan tetapi, liputan yang lebih banyak berorientasi pada realitas wacana tanpa disadari akan menyeret pers menjadi corong pihakpihakyang berkepentingan terhadap peristiwa tertentu. Itu artinya pers membuka diri melakukan trial by the pers.

Di sisi lain, dalam sistem peradilan pidana pers mempunyai kewenangan mengadakan komentar terhadap jalannya peradilan, tetapi pemberitaan tersebut harus bertanggung jawab dan mengedepankan azas praduga tak bersalah sehingga pemberitaan itu tidak merupakan rintangan bagi jalannya peradilan yang fair dan objektif. Hal itu dimaksudkan agar dapat terwujudnya kebebasan pers yang bertanggung jawab sosial dalam keberagaman masyarakat dalam menegakkan integritas dan profesionalitas, maka pers dalam memuat berita harus berdasarkan kode etik yang berlaku. Akan tetapi, perlu dipahami bahwa Undang-undang pidana positif harus dipandang sebagai pembatasan yang sah terhadap kebebasan pers yang secara limitatif dan enumeratif dapat diterapkan bagi mereka yang menyalahgunakan kebebasan tersebut.

\section{ENDNOTE}

${ }^{1}$ Atmakusumah, Kebebasan Pers dan Informasi (Jakarta: Pustaka Sinar Harapan, 1981), hal. 28.

${ }^{2}$ Soebagijo, Sejarah Pers Indonesia (Jakarta: Dewan Pers, 1997), hal.12.

${ }^{3}$ Ibid, hal. 25.

${ }^{4}$ Perlu Perma Agar Dewan Pers Dapat Menjadi Mediator (http:/hukum-online.com 18/9/05).

${ }^{5}$ Muladi, Delik Pers Dalam RUU KUHP, Makalah disampaikan pada seminar sehari tentang Delik Pers Dalam Perkembangan Hukum Indonesia, (Yogyakarta, 4 september 1993), hal. 2.

${ }^{6}$ Pasal 153 ayat (3) UU No. 8 Tahun 1981 tentang Hukum Acara Pidana.

${ }^{7}$ Andi Hamzah, Delik-Delik Pers di Indonesia (Jakarta: PT. Media Sarana Pers,1987), hal. 4-5.

${ }^{8}$ Ibid.

${ }_{9}^{9}$ Mulya Lubis, Langit Masih Mendung: Laporan Keadaan Hak-Hak Asasi Manusia di Indonesia (Jakarta: LBH dan Pustaka Sinar Harapan, 1981), hal. 38 .

${ }^{10}$ Abdurrachman Surjomihardjo, Beberapa Segi Perkembangan Sejarah Pers di Indonesia (Jakarta: LEKNAS-LIPI,1980), hal. 145-146.

${ }^{11}$ Ibid., hal. 148-149.

${ }_{12}^{2}$ Dari aturan inilah kemudian muncul istilah popular dalam kosa kata Bahasa Indonesia "bredel" yang berarti pelarangan terbit untuk sementara atau selamanya terhadap media yang dinilai melanggar aturan pemerintah.

${ }^{13}$ Soebagijo, op.cit., hal. 181.

${ }^{14}$ Ibid.

${ }^{15}$ Mulya Lubis, Ibid., hal. 56.

${ }^{16}$ Kumiawan Junaedhi, Ensiklopedi Pers Indonesia (Jakarta: Gramedia, 1991), hal. 145-146.

${ }^{17}$ Lukas Luwarso, "The Liberation of The Indonesian Press", dalam News in distress: The southeast Asian Media in A Time of Crisis (Philipine: Center for Investigative Joumalism \& Dag Foundation, 1999), hal. 95.

${ }^{18}$ Oemar Seno Adji, Hukum Acara Pidana Dalam Prospeksi (Jakarta: Erlangga, 1976), hal. 262.

${ }^{19} \mathrm{lbid}$.

${ }^{20}$ Liputan besar-besaran dari banyak media yang menyediakan ruang liputan sangat besar dibandingkan dengan liputan peristiwanya.

21 "Penghakiman Pers Melanggar Konstitusi," Suara Pembahanuan, Rabu, 26 Oktober 2008.

${ }_{2}^{2}$ Amir Syamsuddin, "Pers dan Pengadilan”, Kompas, Sabtu, 18 Desember 2004. 


\section{DAFTAR PUSTAKA}

Adji, Oemar Seno. 1986. Hukum Acara Pidana dalam Prospeksi. Jakarta: Erlangga.

Atmakusumah.1981. Kebebasan Pers dan Informasi. Jakarta: Pustaka Sinar Harapan.

Hamzah, Andi.1987. Delik-Delik Pers di Indonesia. Jakarta: PT.Media Sarana Pers.

Junaedhi, Kumiawan. 1991. Ensiklopedi Pers Indonesia. Jakarta: Gramedia.

Luwarso, Lukas. 1999. The Liberation of the Indonesia Press. The Southeast Asia Media: Philipine center for Investigative Joumalsm\& Dag Hammarskjold Foundation.

Lubis, Mulya. 1981. Langit Masih Mendung: Laporan Keadaan Hak-Hak Asasi Manusia di Indonesia. Jakarta: Lembaga Bantuan Hukum dan Pustaka Sinar Harapan.

Muladi. 1993. "Delik Pers Dalam RUU KUHP”, makalah disampaikan pada seminar sehari tentang Delik Pers Dalam Perkembangan Hukum Indonesia. Yogyakarta.

Soebagijo. 1997. Sejarah Pers Indonesia. Jakarta: Dewan Pers.

Sujomihardjo, Abdurrachman. 1980. Beberapa Segi Perkembangan Sejarah Pers di Indonesia. Jakarta: LEKNAS-LIPI. 